\title{
Kinerja Outbound Logistik Susu Segar di Koperasi Peternak Sapi Bandung Utara (KPSBU) Lembang
}

\author{
Performance Analysis of Fresh Milk Outbound Logistics at North Bandung Cattle Farmer Cooperative \\ Lembang
}

\author{
A. Maulidina ${ }^{1}$, E. Taufik ${ }^{2}$, \& A. Atabany ${ }^{2}$ \\ ${ }^{1}$ Sekolah Pascasarjana, Departemen Ilmu Produksi dan Teknologi Peternakan, Institut Pertanian Bogor \\ ${ }^{2}$ Departemen Ilmu Produksi dan Teknologi Peternakan, Fakultas Peternakan, Institut Pertanian Bogor \\ Jalan Agatis, Kampus IPB Dramaga Bogor 16680, Indonesia \\ *Corresponding author: agilmaulidina@gmail.com \\ (Received 01-04-2021; Revised 26-04-2021; Accepted 29-05-2021)
}

\begin{abstract}
North Bandung Cattle Farmer Cooperative (KPSBU) is the single primary cooperative business in Lembang which acts as a forum for dairy farmers in that area to produce quality fresh milk to be distributed to customers. The fresh milk was sold to PT X, PT Y and direct selling to consumers. Distribution of fresh milk to customers is the movement of products out of the factory to consumers, it is called as outbound logistics. The activities during the outbound logistics process mentioned as primary activities that needs attention to their performance and quality of the product. This study was aimed to analyze the performance of the outbound logistics of fresh milk at KPSBU Lembang and quality of fresh milk during the outbound logistics process. The supply chain operation reference-analytical hierarchy process (SCOR-AHP) method was used to analyze the logistics performance. The quality of fresh milk observed included total solid, protein, fat, $\mathrm{pH}$, specific gravity and total plate count. The obtained data were analyzed descriptively. The results showed that the performance of outbound logistics of fresh milk at KPSBU Lembang fell into the good category $(90,20 \%)$. The quality of fresh milk during the outbound logistics process from cooperative to the dairy industry and direct consumers was met the quality standards of customer demand and SNI 3141.1.2011.
\end{abstract}

Keywords: cooperative, fresh milk, outbound logistics performance, quality

\begin{abstract}
ABSTRAK
Koperasi Peternak Sapi Bandung Utara (KPSBU) merupakan koperasi primer tunggal usaha di Lembang berperan sebagai wadah bagi peternak sapi perah di kawasan tersebut dalam memproduksi susu segar berkualitas untuk disalurkan menuju ke pelanggan yaitu PT X, PT Y dan konsumen langsung. Penyaluran susu segar ke pelanggan merupakan pergerakan produk keluar dari pabrik menuju konsumen atau disebut outbound logistik. Aktivitas selama proses outbound logistik merupakan aktivitas primer yang perlu diperhatikan kinerjanya dan kualitas produk yang dihasilkan. Penelitian ini bertujuan untuk mengukur kinerja outbound logistik susu segar di KPSBU Lembang dan kualitas susu segar selama proses outbound logistik. Metode analisis yang digunakan untuk mengukur kinerja outbound logistik susu segar adalah supply chain operation reference-analytical hierarchy process (SCOR-AHP). Pengujian kualitas susu segar meliputi kandungan total bahan kering, protein, lemak, pH, berat jenis dan total jumlah bakteri. Data dianalisis secara deskriptif. Hasil penelitian menunjukkan bahwa nilai kinerja outbond logistik susu segar di KPSBU Lembang yaitu 90,20\% (good). Kualitas susu segar selama proses outbound logistik telah memenuhi standar mutu yang diminta pelanggan dan SNI 3141.1.2011.
\end{abstract}

Kata kunci: kinerja outbound logistik, koperasi, kualitas, susu segar 


\section{PENDAHULUAN}

Perusahaan peternakan sapi perah merupakan perusahaan yang melakukan kegiatan pembibitan, budidaya sapi perah dan pengumpul susu sapi (BPS 2015). Menurut SNI 3141-1:2011 (BSN 2011) definisi susu segar adalah cairan yang berasal dari ambing sapi yang sehat dan bersih, diperoleh dengan cara pemerahan yang benar, kandungan alaminya tidak dikurangi atau ditambah sesuatu apapun dan belum mendapat perlakuan apapun kecuali pendinginan. Peternakan sapi perah yang terus berkembang dan ikut menyumbang jumlah produksi susu segar di Provinsi Jawa Barat terletak di Lembang Kabupaten Bandung Barat sebesar 123099905 liter (BPS 2019). Sentra penghasil susu segar di Lembang dihasilkan oleh anggota peternak dari Koperasi Peternak Sapi Bandung Utara (KPSBU). KPSBU merupakan koperasi primer tunggal usaha di Lembang yang berperan sebagai wadah bagi para peternak sapi perah dalam memproduksi susu segar berkualitas untuk disalurkan ke beberapa IPS (Industri Pengolahan Susu) maupun disalurkan secara langsung ke konsumen. Umumnya, koperasi susu berperan sebagai mediator antara peternak sapi perah dan konsumen yang memiliki peran dalam menentukan jumlah penjualan susu, waktu penjualan, harga susu dan networking dengan pabrik pengolahan susu.

Menurut Bloomberg et al. (2002) outbound logistik merupakan pergerakan produk keluar pabrik menuju ke pelanggan atau konsumen. Aktivitas outbound logistik juga tidak terlepas dari penghantaran (distribusi) produk jadi atau setengah jadi ke konsumen, dalam hal ini yaitu pengiriman susu segar dari KPSBU menuju ke IPS. Aktivitas ini merupakan aktivitas primer yang perlu diperhatikan kinerjanya didalam rantai pasok.

Rantai pasok (supply chain) merupakan konsep baru dalam menerapkan sistem logistik yang terintegrasi, sehingga sangat penting menganggap sistem logistik atau manajemen logistik yang merupakan bagian dari rantai pasok didalam aliran barang, informasi dan keuangan. Pergerakan produk susu segar yang keluar dari koperasi merupakan bagian dari distribusi yang penting untuk diperhatikan. Hal ini dikarenakan perbedaan jarak, ketepatan waktu pengiriman dan kondisi kualitas susu selama diperjalanan mempengaruhi standar penerimaan susu yang telah ditetapkan oleh IPS, yaitu TPC kurang dari $10^{6} \mathrm{cfu} / \mathrm{ml}$ yang digunakan sebagai standar oleh Milk Collection Centers (MCC) sebagai program insentif harga (Chye et al. 2004; Boniface 2012).

Tingginya produksi susu segar tidak akan memberikan keuntungan yang besar jika tidak disertai keefektifan dan efisiensi penyaluran yang baik didalam distribusi. Pendistribusian produk yang efektif selaras terhadap kepuasaan konsumen (Padmantyo dan Saputra 2017). Kepuasaan konsumen dapat diperoleh apabila produk tersebut sesuai dengan ketetapan standar yang diinginkan, sehingga perlu dilakukan pengukuran kinerja dalam upaya meningkatkan kompetensi, mendukung perencanaan tujuan, evaluasi kinerja, perumusan kebijakan startegi dan operasional (Purnomo 2015; Slamet et al. 2011). Akan tetapi pengukuran kinerja outbound logistik sering kali tidak diperhatikan secara komperhensif. Hal ini dapat menyebabkan kualitas produk yang diinginkan tidak tercapai sehingga berdampak pada menurunnya kepuasaan pelanggan sampai pada penolakan produk oleh konsumen. Berdasarkan hal tersebut, pengukuran kinerja outbound logistik susu segar di KPSBU perlu dilakukan dengan menggunakan metode SCOR-AHP (Supply chain operation reference-Analytical hierarchy process).

SCOR-AHP merupakan metode pengukuran kinerja suatu usaha yang dapat mengevaluasi dan menentukan pengambilan keputusan dari permasalahan outbound logistik yang kompleks dan tidak tersusun ke dalam bentuk hierarki. Perbaikan didalam aktivitas outbound logistik merupakan prioritas penting dalam menjaga kualitas susu segar. Oleh karena itu, penelitian ini bertujuan untuk mengukur kinerja outbound logistik susu segar di KPSBU Lembang menggunakan pendekatan SCOR-AHP dan mengukur kualitas fisikokimia dan mikrobiologis susu segar selama distribusi dari koperasi sampai di pabrik susu.

\section{MATERI DAN METODE}

\section{Materi Penelitian}

Penelitian ini menggunakan sampel susu segar yang diambil dari beberapa titik selama aktivitas proses outbound logistik susu segar di KPSBU (Koperasi Peternak Sapi Bandung Utara) Lembang dengan teknik stratified-cluster random sampling dengan confidence level 95\%, sehingga diperoleh empat klaster dari proses outbound logistik susu segar di KPSBU Lembang yaitu susu yang dikumpulkan dari TPK (Tempat Pelayanan Koperasi), susu sebelum didinginkan, susu sesudah didinginkan dan susu yang diterima oleh konsumen meliputi susu yang tiba di IPS (PT $\mathrm{X}$ dan PT Y) maupun konsumen langsung (eceran). Susu segar yang diambil untuk dilakukan analisis sebanyak 250 $\mathrm{ml}$ dengan banyaknya sampel yang berjumlah 48 buah.

\section{Prosedur Penelitian}

Prosedur penelitian ini meliputi pengukuran kinerja outbound logistik susu segar dan pengukuran kualitas susu di beberapa titik selama aktivitas proses outbound logistik susu segar di KPSBU Lembang.

\section{Analisis Kinerja Outbound Logistik}

Kinerja outbound logistik dianalisis menggunakan metode SCOR dengan matriks dari atribut kinerja yang direduksi dan disesuaikan dengan kondisi tempat penelitian disajikan pada Tabel 1. Selanjutnya, setiap matriks akan dihitung dengan persamaan yang sesuai dengan SCC (2012). Tahap berikutnya, penentuan bobot AHP dilakukan dengan pengisian kuesioner perbandingan tiga level dalam SCOR. Sebanyak tiga orang pakar mengisi kuesioner untuk penentuan bobot AHP, yaitu Manager KPSBU Lembang, Kepala Bagian Divisi Produksi Susu KPSBU Lembang dan Kepala Bagian Pengontrolan Kualitas Susu (QC). Nilai perbandingan berpasangan AHP berdasarkan Saaty (2008). Selanjutnya, data kuesioner AHP diolah dengan software expert choice ver 11.0 sehingga diperoleh bobot yang kemudian dianalisis di setiap matriks kinerja sehingga total setiap level adalah 1. Nilai bobot AHP di level 3, dikalikan 
dengan nilai SCOR yang telah dinormalisasi menggunakan benchmarking dengan target kinerja KPSBU menggunakan persamaan menurut Cano et al. (2017). Hasil perhitungan akhir akan dikelompokkan sesuai nilai standar kinerja.

Apabila semakin besar nilai pencapaian akan meningkatkan keuntungan bagi perusahaan persamaan Cano et al. (2017) yang digunakan adalah:

$$
\begin{gathered}
\% \text { Kinerja }=\frac{\text { Nilai aktual }}{\text { Nilai target }} \quad \text { jika nilai aktual } \geq 0 \\
\% \text { Kinerja }=\frac{\text { Nilai aktual }}{\text { Nilai target }}-1 \text { jika nilai aktual }<1
\end{gathered}
$$

Apabila pencapaian dengan nilai yang lebih kecil akan meningkatkan keuntungan perusahaan, persamaan yang digunakan adalah sebagai berikut.

$$
\% \text { Kinerja }=1-\frac{\text { Nilai aktual-nilai target }}{\text { Nilai target }}
$$

Tabel 1. Atribut kinerja dan matriks pengukuran kinerja

\begin{tabular}{ll}
\hline \multicolumn{1}{c}{ Atribut Kinerja } & \multicolumn{1}{c}{ Matriks Pengukuran Kinerja } \\
\hline Reliabilitas & Pemenuhan pesanan \\
& Kesesuaian standar \\
& Kinerja pengiriman \\
Fleksibilitas & Fleksibilitas \\
Responsivitas & Waktu pengiriman \\
& Siklus pemenuhan pesanan \\
Biaya & Biaya \\
Manajemen Aset & Cash to cash cycle time \\
& Persediaan harian \\
\hline
\end{tabular}

Sumber: Apriyani et al. (2018); SCC (2012)

Tabel 2. Klasifikasi nilai standar kinerja

\begin{tabular}{ll}
\hline \multicolumn{1}{c}{ Nilai Kinerja } & \multicolumn{1}{c}{ Kriteria } \\
\hline $95-100$ & Sangat baik (Excellent) \\
$90-94$ & Baik (Above Average) \\
$80-89$ & Sedang (Average) \\
$70-79$ & Kurang (Below Average) \\
$60-69$ & Sangat kurang (Poor) \\
$<60$ & Buruk (Unacceptable) \\
\hline
\end{tabular}

Sumber: Monczka et al. (2011)

Metode penghitungan setiap matriks kinerja adalah sebagai berikut.

$$
\begin{aligned}
& \text { Pemenuhan pemesanan }(\%)=\frac{\text { permintaan yang terpenuhi tanpa menunggu }}{\text { total permintaan konsumen }} \times 100 \% \\
& \text { Kesesuaian standar (\%) } \quad=\frac{\text { total pesanan yang dikirim sesuai standar }}{\text { total pesanan yang dikirim }} \times 100 \% \\
& \text { Kinerja pengiriman }(\%) \quad=\frac{\text { total pengiriman yang dikirim tepat waktu }}{\text { total pesanan yang dikirim }} \times 100 \% \\
& \text { Fleksibilitas (hari) }=\text { Siklus pengadaan produk }+ \text { siklus } \\
& \text { pengemasan produk }+ \text { siklus } \\
& \text { pengiriman produk }
\end{aligned}
$$

Siklus pemenuhan pesanan $($ hari $)=$ Waktu pengadaan + waktu penerimaan + waktu penanganan + waktu pengiriman

Biaya $(\mathrm{Rp}) \quad=$ Biaya pengadaan + biaya penanganan + biaya pengiriman

Cash to cash cycle time (hari) = Rata-rata persediaan + waktu yang dibutuhkan IPS membayar ke KPSBU Lembang - waktu yang dibutuhkan KPSBU Lembang membayar ke peternak

$$
\text { Persediaan harian }(\text { hari })=\frac{\text { rata }- \text { rata persediaan }}{\text { rata }- \text { rata kebutuhan }}
$$

\section{Uji Fisikokimia}

Uji fisikokimia susu segar dilakukan dengan alat Master Pro Milkotester untuk mengetahui kandungan bahan kering tanpa lemak, lemak, protein dan berat jenis (Milkotester 2017).

\section{Uji pH}

Pengujian nilai $\mathrm{pH}$ dilakukan berdasarkan acuan dari SNI 01-2782-1998 tentang metode pengujian susu segar (BSN 1998).

\section{Uji TPC (Total Plate Count)}

Pengujian koloni TPC dilakukan berdasarkan acuan metode SNI 2897:2008 tentang metode pengujian cemaran mikroba dalam daging, telur dan susu, serta hasil olahannya (BSN 2008). Semua koloni yang tumbuh dihitung sebagai TPC dengan metode Bacteriological Analytical Manual (BAM 2001).

\section{Analisis Data}

Data yang diperoleh akan diuji secara deskriptif dan disajikan dalam bentuk tabel dengan maksud memberikan gambaran keadaan data (Suryani dan Hendrayadi 2015).

\section{HASIL DAN PEMBAHASAN}

\section{Kondisi Outbound Logistik Susu Segar di KPSBU Lembang}

Aktivitas yang dilakukan di dalam proses outbound logistik dimulai dari titik awal yaitu susu koperasi yang berasal dari kumpulan susu peternak yang telah diangkut dari masing-masing wilayah tempat pengumpulan susu yang telah diperiksa kualitasnya ditiap-tiap TPK (Tempat Pelayanan Koperasi), kemudian masuk ke titik kedua yaitu bongkar muatan susu selama 30 menit dari mobil pengangkut susu daerah dengan kapasitas $6000 \mathrm{~L}$, ke dalam cooling unit sebelum didinginkan. Tahap berikutnya, susu segar menjalani proses pendinginan di cooling unit selama 4-6 jam untuk menurunkan temperatur susu menjadi $\pm 0-4^{\circ} \mathrm{C}$ supaya kualitas tetap terjaga termasuk ke dalam titik ketiga aktivitas outbound logistik.

KPSBU memiliki lima cooling unit yang tersebar disetiap wilayah yaitu Pojok, Nagrak, Pamecelan, Cibedug dan Pusat, bertujuan untuk memperpendek jarak dan waktu tempuh pada saat mengangkut susu supaya dapat memperkecil peningkatan mikroorganisme didalam susu segar. KPSBU juga memiliki 20 unit mobil pengangkut 
susu (truk susu) dengan tipe tangki yaitu double jacket yang berfungsi untuk menjaga temperatur susu selama perjalanan menuju pabrik pengolahan susu. Kapasitas tangki truk susu sebesar 8500-13000 L dan waktu yang diperlukan untuk pengisian susu segar kedalam tangki truk tersebut yaitu 6085 menit. Setelah proses pendinginan selesai, berat mobil truk susu ditimbang terlebih dahulu sebelum susu segar dialirkan menuju tangki untuk dikirimkan ke IPS.

Susu yang akan didistribusikan diuji kualitasnya terlebih dahulu untuk mengeluarkan surat izin jalan. Pengujian kualitas susu dilakukan disetiap kendaraan yang akan berangkat baik truk susu berkapasitas kecil maupun besar yang dilaksanakan oleh staf laboratorium sebagai pengendali mutu. Truk susu berkapasitas kecil (8000-9000 L) digunakan untuk distribusi susu segar dari koperasi menuju PT X. Rataan kualitas susu segar pada truk berkapasitas kecil yaitu total bahan kering $11.96 \%$, kadar lemak 3.56\%, kadar protein $2.97 \%$ dan total jumlah bakteri $4.3 \times 10^{5} \mathrm{cfu} / \mathrm{ml}$. Truk susu berkapasitas besar ( $\geq 9000-13000$ L) digunakan untuk distribusi susu segar dari koperasi menuju PT Y. Rataan kualitas susu segar pada truk berkapasitas besar yaitu total bahan kering $12.23 \%$, kadar lemak $3.87 \%$, kadar protein $2.92 \%$ dan total jumlah bakteri $9.1 \times 10^{4} \mathrm{cfu} / \mathrm{ml}$. Perbedaan kualitas susu ini dikarenakan susu yang diterima koperasi berasal dari TPK masing-masing wilayah yang berbeda, dikumpulkan dan disatukan di lima cooling unit tersebut sebelum dialirkan menuju truk susu untuk didistribusikan menuju IPS.

Waktu yang dibutuhkan untuk memproduksi susu segar mulai dari susu diterima oleh koperasi sampai dengan susu akan didistribusikan ke IPS yaitu \pm 9-10 jam. Pengiriman susu ke industri dilakukan sekali dalam sehari dengan waktu tempuh selama $\pm 2-3$ jam dengan kuantitas \pm 250 ton. Penetapan harga susu dilakukan berdasarkan kualitas susu yaitu penilaian terhadap kadar lemak, protein, total solid (TS) dan TPC. Harga yang akan dibayar oleh IPS berdasarkan kualitas susu yang disetorkan yaitu TS 11.95\%, kadar lemak $3.5 \%$ dan TPC $<10^{6} \mathrm{cfu} / \mathrm{ml}$. Setiap kenaikan TS, KPSBU akan mendapatkan bonus sesuai dengan kadar kenaikannya.

\section{Kinerja Outbound Logistik Susu Segar}

SCOR dikombinasikan dengan AHP untuk menghasilkan bobot setiap matriks sehingga proses yang paling penting dapat diketahui. Berdasarkan analisis AHP diperoleh hasil pembobotan yang disajikan pada Gambar 1 . Hasil pembobotan menunjukkan bahwa konsistensi penilai pakar adalah 0.06 yang menunjukkan kurang dari 0.1 . Fitria (2013) melaporkan bahwa konsistensi didalam AHP harus kurang dari 10\% untuk menyatakan perhitungan yang dilakukan adalah benar.

Berdasarkan hasil pembobotan, nilai tertinggi pada level pertama adalah perencanaan (0.4025) karena perencanaan merupakan inti proses bisnis yang utama dan bagian terpenting dari semua proses yang dijalankan (Marimin dan Safriyana 2018). Hasil pembobotan pada level kedua, aset memiliki nilai tertinggi yaitu 0.265 . Aset berkaitan dengan kemampuan dalam mengelola persediaan produk dan keuangan yang perlu diperhatikan didalam proses outbound logistik. Atribut kinerja aset adalah atribut kinerja yang mengukur kemampuan rantai pasokan dalam mengelola aset yang dimiliki seefisien mungkin (Isnia et al. 2017).

Kinerja matriks cash to cash cycle time memperoleh bobot tertinggi yaitu 0.179 . Siklus cash to cash merupakan biaya yang dikeluarkan sejak pengadaan bahan baku susu sapi yang kemudian didistribusikan ke IPS hingga menerima pembayaran atas produk susu segar yang diproduksi oleh koperasi. Rakhman et al. (2018) menyatakan siklus cash to cash merupakan aktvitas prioritas yang harus dilakukan monitoring berkaitan dengan kinerja aset. Melalui pembobotan kinerja suatu proses bisnis dapat mengetahui prioritas yang didahulukan didalam peningkatan kinerja.

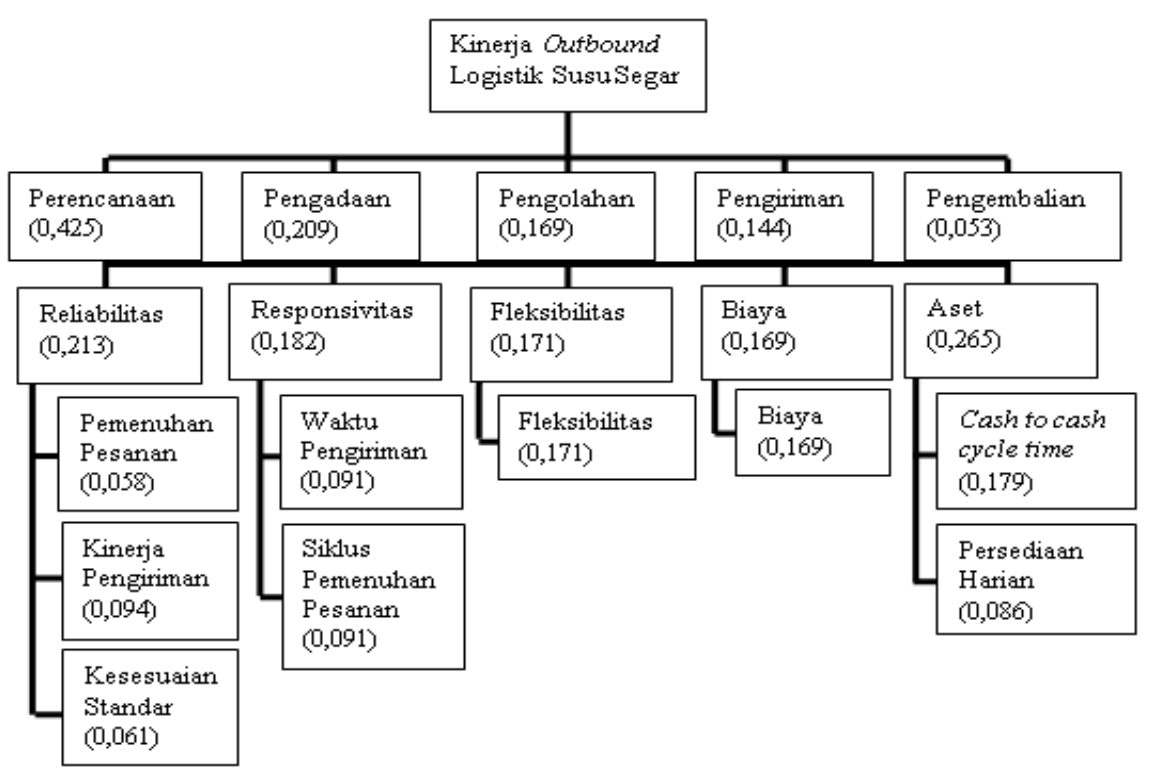

Gambar 1. Hierarki hasil pembobotan AHP matriks kinerja outbound logistik susu segar 
Tabel 3. Nilai kinerja outbound logistik susu segar di KPSBU Lembang

\begin{tabular}{llcc}
\hline \multirow{1}{*}{$\begin{array}{c}\text { Atribut } \\
\text { Kinerja }\end{array}$} & Matriks Kinerja & \multicolumn{2}{c}{ \% Nilai } \\
\cline { 3 - 4 } & & $\begin{array}{c}\text { Pembobotan } \\
\text { AHP }\end{array}$ & $\begin{array}{c}\text { Matriks } \\
\text { Kinerja }\end{array}$ \\
\hline Reliabilitas & Pemenuhan pesanan & 5.80 & 5.22 \\
& Kinerja pengiriman & 9.40 & 9.40 \\
& Kesesuaian standar & 6.10 & 6.10 \\
Responsivitas & Waktu pengiriman & 9.10 & 9.10 \\
& Siklus Pemenuhan & 9.10 & 7.55 \\
Fleksibilitas & pesanan & & \\
Biaya & Fleksibilitas & 17.10 & 17.10 \\
Aset & Biaya & 16.90 & 14.70 \\
& Cash to cash cycle & 17.90 & 14.32 \\
& time & & \\
& Persediaan harian & 8.60 & 6.71 \\
\hline
\end{tabular}

Prioritas peningkatan kinerja outbound logistik susu segar pada tiap levelnya adalah perencanaan (0.425), aset (0.265) serta cash to cash cycle (0.179). Keempat aspek inilah yang kemudian dijadikan bahan pertimbangan utama dalam penyusunan strategi peningkatan kinerja outbound logistik susu segar di KPSBU pada tahap berikutnya.

Berdasarkan data yang disajikan pada Tabel 3, nilai kinerja outbound logistik susu segar di KPSBU Lembang sebesar 90.20\% termasuk kedalam kategori baik (good). Hasil ini menunjukkan bahwa penerapan manajemen outbound logistik di KPSBU perlu dilakukan peningkatan kinerja. Hampir setiap target yang ditetapkan oleh KPSBU untuk setiap matriks kinerja sudah tercapai. Persentase nilai matriks kinerja terendah yaitu pemenuhan pesanan. Rendahnya nilai matriks kinerja ini disebabkan oleh besarnya jumlah permintaan susu di IPS yang tinggi dibandingkan jumlah produksi susu segar yang diproduksi oleh KPSBU sehingga tidak tercapainya pemenuhan pesanan.

Persentase nilai tertinggi yaitu pada matriks kinerja fleksibilitas. Nilai fleksibilitas yang tinggi menunjukkan bahwa KPSBU mampu memperkirakan perubahan permintaan dan membuat perhitungan dalam proses perencanaan dengan menambahkan persediaan harian (stok). Fleksibilitas juga menggambarkan kemampuan koperasi dalam menghadapi suatu perubahan kondisi baik perubahan yang berasal dari internal ataupun eksternal. Selain itu juga, fleksibilitas menjadi faktor yang dipertimbangkan dalam menghadapi persaingan, melalui fleksibilitas diharapkan kepuasan pelanggan dapat tercapai. Kepuasan konsumen akan meningkatkan keuntungan dan membentuk hubungan jangka panjang yang memberikan keuntungan berupa loyalitas konsumen (Khuong dan Dai 2016).

\section{Kualitas Susu Segar}

Kualitas susu yang diterima oleh IPS semakin bagus memberikan efek positif terhadap harga jual sehingga KPSBU memperoleh reward berupa bonus tambahan harga susu atas kenaikan kualitas. Hal ini selaras dengan hasil penelitian yang dilakukan oleh Hertanto (2014) menunjukkan bahwa harga susu per liter sangat ditentukan oleh kualitas susu yang memberikan pengaruh terhadap penerimaan susu secara total.

Tabel 4. Kandungan total solid, lemak dan protein susu di setiap titik outbound logistik

\begin{tabular}{cccc}
\hline \multirow{2}{*}{$\begin{array}{c}\text { Titik } \\
\text { Outbound } \\
\text { Logistik }\end{array}$} & $\begin{array}{c}\text { Total Solid } \\
(\%)\end{array}$ & $\begin{array}{c}\text { Lemak } \\
(\%)\end{array}$ & $\begin{array}{c}\text { Protein } \\
(\%)\end{array}$ \\
\hline A & $12.33 \pm 0.14$ & $4.16 \pm 0.25$ & $3.01 \pm 0.05$ \\
B & $12.30 \pm 0.09$ & $3.99 \pm 0.24$ & $2.99 \pm 0.02$ \\
C & $12.29 \pm 0.12$ & $3.95 \pm 0.12$ & $2.97 \pm 0.06$ \\
D & $11.98 \pm 0.08$ & $3.52 \pm 0.13$ & $2.96 \pm 0.05$ \\
E & $12.26 \pm 0.12$ & $3.91 \pm 0.13$ & $2.92 \pm 0.04$ \\
F & $12.01 \pm 0.11$ & $3.52 \pm 0.11$ & $2.90 \pm 0.06$ \\
\hline
\end{tabular}

Keterangan : A = Susu yang dikumpulkan dari TPK (susu koperasi); B = Susu sebelum didinginkan; $\mathrm{C}=$ Susu sesudah didinginkan; D = Susu yang diterima oleh PT X; E = Susu yang diterima oleh PT Y; F = Susu yang diterima oleh konsumen langsung (eceran)

Kualitas susu ditentukan berdasarkan komponen penyusun susu terdiri atas kadar lemak, protein, laktosa, vitamin, dan mineral atau disebut kandungan bahan kering (total solid). Kandungan total solid yang bagus akan berdampak pada harga susu yang dijual. Tabel di atas menjelaskan bahwa rata-rata kandungan total solid mengalami penurunan seiring dengan aktivitas proses outbound logistik susu segar yang semakin panjang. Penurunan kualitas susu segar terjadi karena pemanfaatan nutrisi yang terkandung didalam susu untuk aktivitas bakteri. Saleh (2004) memaparkan bahwa susu dapat tercemar oleh bakteri karena susu mengandung bahan-bahan yang diperlukan oleh bakteri untuk hidup seperti protein, mineral, karbohidrat, lemak dan vitamin, apabila terjadi pencemaran oleh bakteri maka secara otomatis susunan dan keadaan susu juga akan ikut berubah.

Penurunan kandungan total solid diikuti juga dengan penurunan kadar lemak maupun kadar protein. Hal ini sesuai dengan pendapat Martindah dan Saptati (2014) bahwa total solid adalah gabungan dari lemak dan solid non fat meliputi protein, laktosa dan unsur elemen lainnya. Apabila kandungan total bahan kering terjadi penurunan maka dapat berakibat menurunnya kadar lemak ataupun kadar protein. Kualitas susu segar selama aktivitas outbound logistik mulai dari susu di koperasi sampai pada susu diterima oleh pelanggan telah memenuhi standar mutu baik yang disyaratkan oleh IPS (TS 11.95\%, kadar lemak $3.5 \%$ dan TPC $<10^{6} \mathrm{cfu} / \mathrm{ml}$ ) dan juga SNI 3141.1.2011 yaitu TS $10.8 \%$, lemak $3.0 \%$ dan protein $2.80 \%$ (BSN 2011).

Nilai rata-rata $\mathrm{pH}$ sampel susu segar yang diamati mulai dari koperasi sampai pada konsumen bervariasi yaitu 6.51-6.63. Selama aktivitas proses outbound logistik susu segar, pihak koperasi masih tetap mempertahankan dan menjaga kualitas susu supaya tetap terjaga sesuai standar nasional meskipun nilainya beragam. Asmaq dan Marisa (2020) melaporkan lamanya masa penyimpanan dapat 
Tabel 5. Kandungan $\mathrm{pH}$, berat jenis dan TPC susu di setiap titik outbound logistik

\begin{tabular}{cccc}
\hline \multirow{2}{*}{$\begin{array}{c}\text { Titik } \\
\text { Outbound } \\
\text { Logistik }\end{array}$} & $\mathrm{pH}$ & \multicolumn{3}{c}{ Nilai rata-rata } \\
\cline { 2 - 4 }$\left(\mathrm{gram} / \mathrm{cm}^{3}\right)$ & $\begin{array}{c}\text { Total Plate Count } \\
\left(\text { Log cfu } \mathrm{mL}^{-1}\right)\end{array}$ \\
\hline $\mathrm{A}$ & $6.63 \pm 0.08$ & $1.028 \pm 0.00$ & $5.04 \pm 0.11$ \\
$\mathrm{~B}$ & $6.61 \pm 0.12$ & $1.028 \pm 0.00$ & $5.35 \pm 0.06$ \\
$\mathrm{C}$ & $6.59 \pm 0.05$ & $1.028 \pm 0.00$ & $5.47 \pm 0.14$ \\
$\mathrm{D}$ & $6.57 \pm 0.06$ & $1.028 \pm 0.00$ & $5.71 \pm 0.14$ \\
$\mathrm{E}$ & $6.56 \pm 0.08$ & $1.028 \pm 0.00$ & $5.52 \pm 0.20$ \\
F & $6.51 \pm 0.12$ & $1.028 \pm 0.00$ & $5.60 \pm 0.14$ \\
\hline
\end{tabular}

Keterangan : A = Susu yang dikumpulkan dari TPK (susu koperasi); $\mathrm{B}=$ Susu sebelum didinginkan; $\mathrm{C}=$ Susu sesudah didinginkan; D = Susu yang diterima oleh PT X; E = Susu yang diterima oleh PT Y; F = Susu yang diterima oleh konsumen langsung (eceran)

mempengaruhi kualitas susu khususnya $\mathrm{pH}$. Penanganan susu yang salah dapat meningkatkan pertumbuhan mikroorganisme pada susu. Kondisi susu yang berubah menjadi asam menandakan adanya kontaminasi bakteri. Rata-rata kandungan berat jenis susu disetiap titik outbound logistik mulai dari titik awal susu di koperasi sampai dengan susu diterima oleh IPS maupun dijual eceran memiliki nilai yang sama yaitu $1.028 \mathrm{gram} / \mathrm{cm}^{3}$. Tidak ada perubahan berat jenis selama aktivitas outbound logistik, hal ini menunjukkan bahwa tidak ada campuran penambahan air didalam susu.

Kualitas susu dapat juga ditentukan dari keberadaan jumlah bakteri didalamnya. Kontaminasi bakteri dapat mengubah sifat fisikokimia dan organoleptik sehingga kerusakan susu dapat terjadi dengan cepat. Rata-rata kandungan TPC susu segar disetiap titik outbound logistik mengalami peningkatan selaras dengan penurunan nilai pH. Kandungan TPC susu segar pada saat diterima oleh konsumen mengalami peningkatan dari setelah susu didinginkan sebelum distribusi. Kandungan TPC di PT X lebih tinggi dibandingkan PT Y dan eceran. Akan tetapi, TPC susu segar pada saat diterima oleh PT Y paling rendah dibandingkan keduanya. Perbedaan ini disebabkan oleh perbedaan jarak dan waktu tempuh serta lokasi cooling unit (unit pendinginan susu) yang berbeda sebelum didistribusikan. Aktivitas proses outbound logistik susu segar dari koperasi menuju IPS maupun konsumen langsung tidak mempengaruhi penurunan kualitas susu segar menjadi tidak layak, artinya pihak koperasi telah memperhatikan penanganan susu segar mulai dari hulu sampai hilir dan mampu mempertahankan dan menjaga kualitas sesuai standar nasional. Mutu syarat susu segar berdasarkan SNI 3141.1.2011 adalah pH 6.3-6.8, berat jenis 1.027-1.028 $\mathrm{gram} / \mathrm{cm}^{3}$ dan TPC maksimal $106 \mathrm{cfu} / \mathrm{mL}$ (BSN 2011).

\section{KESIMPULAN}

Kinerja outbound logistik susu segar di KPSBU Lembang menunjukkan hasil yang baik (good) yaitu 90.20\% sehingga mampu memproduksi susu segar berkualitas sesuai standar penerimaan susu yang telah ditetapkan oleh industri pengolahan susu. Kualitas susu segar selama proses outbound logistik mulai dari koperasi sampai dengan industri pengolahan susu maupun konsumen langsung sesuai dengan standar kualitas permintaan pelanggan dan juga SNI 3141.1.2011 tentang susu segar.

\section{DAFTAR PUSTAKA}

BAM (Bacteriological Analytical Manual). 2001. Aerobic Plate Count. New York (US): FDA Departement of Health and Human Services.

BPS (Badan Pusat Statistik). 2015. Statistik Perusahaan Sapi Perah Tahun 2015. Jakarta (ID): BPS.

BPS (Badan Pusat Statistik). 2019. Provinsi Jawa Barat dalam Angka 2019. Jawa Barat (ID): BPS.

BSN (Badan Standarisasi Nasional). 1998. SNI 01-27821998 tentang Metode Pengujian Susu Segar. Jakarta (ID): BSN.

BSN (Badan Standarisasi Nasional). 2008. SNI 28972008 tentang Metode Pengujian Cemaran Mikroba dalam Daging, Telur dan Susu, serta Hasil Olahannya. Jakarta (ID): BSN.

BSN Badan Standarisasi Nasional). 2011. SNI 3141.1:2011 tentang Susu Segar Bagian-1: Sapi. Jakarta (ID): BSN.

SCC (Supply Chain Council). 2012. SCOR. Supply Chain Operations ReferenceModel Revision 11.0 (US).

Apriyani, D., R. Nurmalina, \& Burhanuddin. 2018. Evaluasi kinerja rantai pasok sayuran organik dengan supply chain operation reference (SCOR). J.Ilm.Man. 8(2):2018.

Asmaq, N., \& J. Marisa. 2020. Karakteristik fisik dan organoleptik susu segar di Medan Sunggal. JPI. 22(2): 168-175.

Bloomberg, \& J. David. 2002. Logistic 4th edition. Great Britain: Prentice Hall International Inc.

Boniface, B. 2012. Producer relationships segmentation in Malaysia's milk supply chains. British Food Journal. 114(10): 1501-1516.

Cano, J. A., J. J. Vergara, \& F. A. Puerta. 2017. Design and implementation of balanced scorecard in a Colombian company. Espacios. 38(31): 19-32.

Chye, F. K., A. Abdullah, \& M. K. Ayob. 2004. Bacteriological quality and safety of raw milk in Malaysia. Food Microbiology. 21: 535-541.

Hamidah, M., A. H. Yusra, \& J. Sudrajat. 2015. Analisis nilai tambah agroindustri kripik ubi di Kota Pontianak. JSEA. 4(2): 60-73.

Hertanto, B. S. 2014. Kajian komparatif parameter ekonomi (harga susu dan pakan) terhadap efisiensi penggunaan teknologi pakan pada usaha sapi perah. Sains Peternakan. 12(1): 49-55.

Isnia, M., Y. Hariyati, \& A. Kusmiati. 2017. Analisis manajemen rantai pasok susu sapi perah pada Koperasi 
Peternak Galur Murni di Kecamatan Sumberbaru Kabupaten Jember. JSEP. 10(1): 65-77.

Khuong, M. N., \& N. Q. Dai. 2016. The factors affecting customer satisfaction and customer loyalty-a study of local taxi companies in Ho Chi Minh City, Vietnam. International Journal of Innovation Management Technology. 7(5):228-233.

Marimin, \& Safriyana. 2018. Evaluation of palm oil supply chain's performance, added value, and performance improvement: a case study at X Co.IOP Conference Series: Earth and Environtal Science Volume 196 2018; 2017 Nopember 6-8; Selangor, Malaysia. Bristol (UK): IOP Publishing. hlm.1-13.

Martindah, E., \& R. A. Saptati. 2014. Peran dan upaya koperasi peternak sapi perah dalam meningkatkan kualitas susu di Jawa Barat. JITV. 19(2): 476-483.

Monczka, R., R. J. Trent, \& R. B. Handfield. 2011. Purchasing and Supply Chain Management 5th Edition. Ohio (US): Cengage Learning.

Padmantyo, S., \& A. Saputra. 2017. Peranan manajemen rantai pasokan terhadap kualitas produk dan efisiensi distribusi. Didalam: Kholis N, Puspawati D, editor. Prosiding Seminar Nasional dan the 4th Call for Syariah Paper. 2017 Juli 22-25; Universitas Muhammadiyah Surakarta. Surakarta. hlm. 191-197. ISSN 2460-0784.
Purnomo, A. 2015. Analisis kinerja rantai pasok menggunakan metode scor di industri tekstil sektor industri hilir (studi kasus pada perusahaan garmen PT Alas Indah Remaja Bogor). Didalam: Sugati D, Kadiman S, Setyawan A, editor. Prosiding Seminar Nasional Rekayasa Teknologi Industri dan Informasi ke-10. 2015 Desember 19; Sekolah Tinggi Teknologi Nasional Yogyakarta. Yogyakarta. hlm. 739-746.

Rakhman, A., Machfud, \& Y. Arkeman. 2018. Kinerja manajemen rantai pasok dengan menggunakan pendekatan metode supply chain operation reference (SCOR). JABM. 4(1): 106-118.

Saaty, T. L. 2008. Decision making with the analytic hierarchy process. Int.J.Services.Sciences. 1(1): 83-98.

Slamet, A. S., Marimin, Y. Arkeman, \& F. Udin. 2011. Studi peningkatan manajemen rantai pasokan sayur dataran tinggi di Jawa Barat. Agritech. 31(1): 60-70.

Suryani, \& Hendryadi. 2015. Metode Riset Kuantitaif: Teori dan Aplikasi pada Penelitian Bidang Manajemen dan Ekonomi Islam. Jakarta (ID): Kencana. 